\title{
New professionalism in austere times: the employment experiences of early career teachers in Scotland
}

\author{
Moira Hulme ${ }^{a}$ and Ian Menter ${ }^{b}$ \\ ${ }^{a}$ University of Glasgow, ${ }^{b}$ University of Oxford
}

\begin{abstract}
International concern to raise educational standards and improve teacher quality has directed attention to the need to sustain career long professional learning. Teacher induction and early professional learning (during years 2-6) have been associated with patterns of attrition and improved pupil outcomes. As the economic crisis impacts on public sector employment, the rhetoric of professionalism stands in contrast to the employment experiences of many recently qualified teachers. This article draws on interviews with twenty early career teachers (ECTs) in Scotland who achieved full registration from 2006. Work histories drawn from this smallscale study challenge the implicit assumptions of staged models of teacher development and draw attention to the increasing fragmentation and casualization of experience in the teacher labour market.
\end{abstract}

\section{Key words}

Early career professional development, teacher employment, induction.

\section{Introduction}

National education systems are routinely associated with discourses of economic decline and renewal. Concern with educational standards (in the service of economic growth) has directed attention to 'teacher quality' and teacher education across Anglophone nations (European Commission 2007; OECD 2007a, 2011). There has been international concern to attract 'talented and motivated people' to the profession and to sustain professional growth across the career course (OECD 2005, Auguste et al. 2010). A focus on selection, retention and early professional learning is evident in different strategies to reform teacher education in Scotland (Donaldson 2011), England (Department for Education 2010), Ireland (Teaching Council 2011), Australia (Caldwell and Sutton 2010a/b), New Zealand (Education Review Office 2005) and the United States (National Research Council 2010). There is consensus that strategies to improve teacher quality need to extend beyond selection and certification to how the early years within the profession are experienced, especially the influence of school context. Research has stressed that teacher quality is inextricably linked with the conditions that support or inhibit professional learning in the workplace (Johnson 2006). As Feiman-Nemser $(2001,1026)$ notes the first five years of teaching are an 'intense and formative time in learning to teach'.

Early literature tended to depict teacher development as a 'staged' rather than a contingent process. Feiman-Nemser and Remillard $(1996,66)$ describe 'an initial stage of survival and discovery, a second stage of experimentation and consolidation, and a third stage of mastery and stabilisation.' This model of cumulative skill acquisition - novice-competent-expert underpins the continuum of teacher education: pre-service, induction (full registration) through to accomplished teaching (chartered teacher/master teacher status). Attention to teachers' life cycles challenges assumptions of stepwise progression by showing how achieving competence can be followed by 'serenity', 'conservatism' and 'disengagement' (Huberman 1989, 1993). Recent research has pointed to the discontinuous, unstable and recursive nature of professional learning and identity formation (Day 2008, Scott and Dinham 2008, McNally et al. 2008). 
Rather than transition from the periphery (novice) to the centre (expert), attention has turned to what is meant by skilful practice, how it is achieved and workplace practices that sustain professional skill. The stage model has been challenged for understating within group variance (by emphasising differences between novice and experienced teachers); and for neglecting possibilities for 'movement outward' i.e. learning from those with less experience (Dall'Alba and Sandberg 2006). Acknowledgement of circularity, contingency and discontinuity is particularly pertinent in conditions of over-supply characterised by higher rates of intermittent employment/broken service.

There remain relatively few large-scale longitudinal studies that address the complexity of professional learning through transition points in teachers' lives. Empirical studies with a focus on early career development include: Teachers of Promise in New Zealand (Cameron et al. 2006, 2007); Retaining Effective Early Career Teachers in Australia (Schuck et al. 2011); The Project on the Next Generation of Teachers (Johnson 2004) and the Beginning Teacher Longitudinal Study (Kaiser 2011) in the USA; Becoming a Teacher (Hobson et al. 2009) and Variations in teachers' work, lives and effectiveness (Day et al. 2006) in England. Unlike Scotland, these studies were commissioned in national contexts characterised by recurrent teacher shortages (varying according to subject and region) and high rates of early career attrition. More common are small-scale studies of the choices and expectations of recent entrants to the profession. These have focused on: particular groups such as the academically able (Clayton and Shoemaker 2007) and career changers (Anthony and Ord 2008, Griffiths 2011); the influence of mentoring practices (Moor et al. 2005, Parker et al. 2009, Moir et al. 2009); the affordances of school culture including teacher autonomy and opportunities for leadership (Ingersoll 2001, Turnbull 2004, McCormack et al. 2006); and the intersection of workplace culture with personal dispositions to learning (Burn et al. 2010, Williams and Prestage 2001).

The global economic crisis that developed from 2008 has impacted on the teacher labour market. Employment is more precarious and tenure longer to achieve. Studies of beginning teachers' employment and development experiences that acknowledge the issue of oversupply in the post-crisis period have appeared in Australia (Pietsch and Williamson 2010) and Scotland (Fenwick 2011, Fenwick and Weir 2010). The research base on appointment practices in teaching is not extensive and has been confined to contexts where there is diversity of school type and training routes (Mason and Schroeder 2010). Clearly teachers employed on an intermittent basis face particular challenges. Jenkins et al. $(2009,72)$ describe how 'causals are required to continually reframe, owing to the different places, schools, staffs, Key Learning Areas [curriculum] and students with who they are obligated to work'. There is limited largescale research in the UK on the transitional decisions of those who decide to stay, move or leave the profession (Smithers and Robinson 2003, Smethem 2007, Hutchings 2011, Allen et al. 2012). Where statistical modelling of teacher tenure is used on a significant scale, such as the United States, the dominant rationale appears to be teacher evaluation (based on student outcomes) (Henry et al. 2011). A primary focus on 'teacher effects' may detract attention from the working conditions that frame practice. The study reported here sought to connect teacher learning with employment experiences in the early career phase during a period of significant pressure on the public sector.

\section{Background: teacher induction and employment in Scotland}

The system of support for newly qualified teachers in Scotland has been acclaimed as 'world class' (OECD 2007, 15); the 'gold standard' of 'exemplary' teacher induction (McCormac 
2011, 21).) Introduced in 2002, the Teacher Induction Scheme (TIS) offers a one-year salaried training place (£21,438 in 2011) for probationary teachers who have met the Standard for Initial Teacher Education (GTCS 2006a). During induction beginning teachers must meet the Standard for Full Registration (SFR) to be eligible for appointment to permanent posts in maintained schools (GTCS 2006b). Towards the end of initial teacher education students rank five local authorities in order of preference (from the 32 local authorities in Scotland). A minority opt for a preference waiver, which carries a financial incentive and may result in deployment to less well subscribed areas of the country. Newly qualified teachers have a 0.8 full-time equivalent timetable (an average of 18 hours per week across the school year) (GTCS 2012). Each teacher is assigned a 'supporter' or mentor from among the school staff. In addition, local authority coordinators organise programmes of professional development for new teachers in their region.

Whilst highly prized the TIS has been drawn into deliberation on how to sustain commitments to education in challenging economic circumstances. The social contract between employers, teachers' associations and government is under strain. Tensions are evident between an established and powerful professional discourse on teacher education and capacity to sustain frontline services and teachers' terms and conditions. A review of teacher education, Teaching Scotland's Future (Donaldson 2011), which sought to strengthen the induction scheme, was quickly followed by a review of teacher employment that addressed issues of impact and affordability (McCormac 2011). Employers' organisations called on the Scottish Government to re-examine the 2001 teachers' agreement (SEED 2001) in the context of year-on-year financial pressure. The 2007 concordat between local government and the Scottish Government places responsibility for the delivery of national commitments relating to school education with local authorities. Education budgets compete with other pressing public spending priorities (Scottish Government 2010a). The Centre for Public Policy for Regions $(2012,4)$ estimates an $18 \%$ real terms cut in public expenditure between 2009-10 and 2016-17.

Staffing costs are the largest on-going investment in education and many local authorities have reduced teacher numbers. Between 2007 and 2010 the fall in teacher numbers $(-4.8 \%)$ exceeded the fall in pupil numbers $(-2.8 \%)$ (Kidner 2011). The teaching workforce fell from 55,083 in 2007 to 51,431 in 2010 (Scottish Government 2011a). The proportion of new teachers not employed in teaching in Scotland in the October following induction rose from 5.3\% to 27\% between October 2005 and 2010 (GTCS 2010a). According to the GTCS probationer survey the proportion of new teachers employed on permanent teaching contracts decreased from $66 \%$ to $18 \%$ between October 2005 and 2010 (GTCS 2010b). The annual survey of former probationers in 2011 reported an increase in unemployment from 13\% to 16\% among newly qualified respondents (GTCS 2011). Commenting in December 2008 the then Education Secretary, Fiona Hyslop, noted that the teacher induction scheme had 'displaced' rather than addressed the problem of new teacher unemployment (Kidner 2011,10). Negative reports appeared in the Scottish education media and popular press. The Times Educational Supplement Scotland greeted each new school year with reports of a 'Grotesque waste of talent' (29/08/2008), 'Probationer jobs slump' (21/08/2009), 'Hard times for new teachers' (20/08/2010), 'Only 1 in 5 NQTs lands a full-time job' (17/06/2011), 'Three-quarters of probationers fail to secure full-time posts' (15/06/2012). Questions were raised in the Scottish Parliament. New teacher employment became a political issue in the run up to the Scottish Parliament election of 2011. The Scottish budget 2011-12 contained commitments to secure vacancies for teachers finishing probation and tackle longer-term teacher unemployment (Scottish Government 2010a, 17). 


\section{The study}

This small-scale exploratory study aimed to provide an insight into the employment and development experiences of teachers on completion of the one year induction scheme. It is concerned with how the process of entering the profession and securing employment is experienced or lived during a time of change. The research addressed the following the questions:

- What are the experiences of early career teachers in the first five years post qualification?

- What is the impact of the teacher induction scheme in supporting transition into teaching?

\section{Methodology}

The study reported here is a pilot study. At this developmental stage, an interpretive approach was employed to generate rich data on the particular experiences of a small group of early career teachers. Retrospective accounts were generated through interviews. Analysis of the large-scale secondary dataset generated by the Scottish Government teacher census was discounted at this juncture for the following reasons: (i) this approach would not yield rich textured data on early career teachers' (ECT) experiences and perceptions; (ii) variable types and coding have been revised over the life of the census rendering longitudinal analysis problematic; (iii) problem of missing data specifically relevant to ECT experiences i.e. returns from schools exclude temporary/supply teacher deployment.

The research team was interested in hearing from teachers who had qualified from 2006 in fulltime, part-time, permanent, temporary or occasional employment. Care was taken to include 'hard to reach' participants - teachers with intermittent or no employment. Participants were recruited using three approaches: (i) an email invitation was sent by the GTCS to a sample of one hundred teachers who had qualified from the University of Glasgow between 2006 and 2009 (primary and secondary courses); (ii) an open letter of invitation was distributed via the Scottish Secondary Teachers' Association (this invitation resulted in 6 interviews); (iii) an invitation was posted on the electronic discussion boards for 'supply teachers' and 'unemployed teachers' of the Times Educational Supplement Scotland (producing 3 interviews). Advance communication clarified the purpose of the study and the themes to be explored:

- the transition from university into employment

- experiences of induction and support during the first year of teaching

- support and development needs following the first year

- experiences since achievement of full professional status

- longer-term career development

Twenty semi-structured interviews of between forty-five and seventy minutes duration were conducted in May-June 2011. Interviewees were given the choice of face-to-face interviews at two university campuses in the west and south of Scotland; or a telephone or Skype interview at a time of their choosing (including evenings and weekends for privacy and convenience). Five interviews were conducted face-to-face; one via Skype video call and fourteen by telephone. Whilst telephone interviews do not provide visual cues this media enabled participation of teachers drawn from a wider geographical area. Flexibility over the timing and location of the interview may have increased a sense of privacy and anonymity for respondents (Sturges and Hanrahan 2004). All interviews were recorded and fully transcribed. Within-case 
and across-case analysis was conducted using NVivo. Transcripts were interrogated drawing on research literature, policy developments and deliberation in team meetings.

Participants included fourteen women and six men who had trained at three Scottish universities. Interviewees were between 21 and 47 years of age. The mean age of 30.5 years is consistent with the wider population of new teachers in Scotland. Three-quarters of respondents had previous employment outside education before training to teach. Nine participants had qualified as primary teachers; the others had qualified to teach in nine different secondary school subjects. Ten interviewees were currently employed on temporary, fixed-term or supply posts in Scotland. Seven teachers had been appointed to permanent posts in Scottish schools (all secondary) within four years of achieving full registration. Interviewees were dispersed across twelve local authorities from Aberdeenshire in the north to Dumfries and Galloway in the south. One teacher was working in the independent sector in England and another at a British School in the Middle East. One respondent who qualified in 2008 had taken full-time employment outside teaching but was actively seeking a teaching post.

\section{Findings}

The following three sections report teachers' experiences of transition from induction to full registration and first posts. Analysis of transcripts indicates that a stable developmental induction period is followed by divergent pathways distinguished by tenure status. The concerns of teachers who had yet to achieve 'permanency' are expressed in terms of exclusion, isolation and uncertainty. Teachers appointed to permanent posts orient towards promotion or self-realisation within or outside the mainscale teacher role. Individualisation is a dominant theme, which is experienced positively as autonomy by those with secure tenure and negatively as casualization by those at the periphery.

\section{Experiences of the induction year}

Interviewees offered generally positive accounts of professional learning during induction. Whilst there was some variation in approaches to mentoring (more or less facilitative or directive) expectations of continuing support were met. Probationers valued day-to-day peer support as well as formal support at key developmental stages in the induction process. One authority with a high number of smaller and rural schools operated an effective buddy scheme, pairing recently appointed teachers with probationers. All interviewees valued the timetable reduction, especially in the early stages, and nineteen received their full entitlement. In addition to reading and preparation, this time was used for a range of activities including observation of interesting practice in other classes; working with emotional and behavioural support teams; and visits to partner schools to understand pupil transition. Credibility and timeliness were regarded as important elements of CPD for new teachers. Formal profile reports and monthly local authority inputs were regarded as less helpful than school-level in situ support that addressed emergent needs. Profile completion was sometimes interpreted as 'ticking boxes' rather than promoting critical reflection on practice. If authority sessions were criticised, this was for providing input regarded as 'too generic', repeating material addressed elsewhere or needed at an earlier stage in the school year. However, authority-wide twilight sessions did provide critical distance and networking opportunities for new teachers to learn about practice in a wider range of settings. Significant inhibitors of professional learning were reported on conclusion of this structured and salaried period of statutory support.

\section{Post induction employment - 'taking a nose dive'}


It is not uncommon for new teachers to experience temporary employment before securing a permanent post. However few interviewees appeared prepared for an increasingly competitive and contracting national and regional labour market on leaving the security of the salaried induction year. There was little evidence that future employment prospects were considered when selecting an induction region. Council choice was influenced by family connections, university experience, a manageable commute or continuity in childcare arrangements. The financial incentive influenced three candidates to take the preference waiver; one of whom suggested job opportunities might be better in rural authorities. As council budgets have contracted, and political pressure to raise post-induction employment rates has increased, local authority labour markets have become more volatile and closed. It is now common for opportunities arising from retirement to be offered first to teachers who have completed their probation period within that authority and remain on the supply register for that region. The need to 'sit tight' and show commitment to a region inhibits geographical mobility and is not without risk. Interviewees reported that jobs advertised as permanent posts were pulled prior to interview and re-advertised as temporary fractional contracts to maintain an appearance of high employment. For one short listed candidate this meant a further eight months juggling part-time temporary and supply contracts at two schools.

'The way things work around here it's very much once you're in, you're in. A lot of the jobs were advertised internally. So I made the decision to sit it out and wait basically. To try to get enough supply work to keep me going'

ECTs expressed frustration that newly qualified teachers were 'let go' after the census date for teacher employment surveys. It was alleged that maternity leave periods were being covered by probationers as core staffing, rather than allocated to supply pools and that primary supply teachers' continuous service was broken so that teachers could not claim transfer to permanent posts: 'I put in my letter of permanency. Then of course they didn't give me any work for five weeks.' Engagement in episodic short-term temporary work stalled professional growth as new teachers repeatedly experienced the challenges of starting over in new settings. Teachers with intermittent employment felt their prospects were reduced by not having the opportunity to work with their 'own' classes and develop skills in longer-term planning and assessment. Such fragmentation had a damaging impact on their identity as a teacher.

'You lose some of your confidence. You start off with this great year, a fair amount of support and you learn a lot. Then to have six months of no work, or a week's work; your self esteem takes a nose dive... You don't start from scratch but it takes you a long time to remember all the strategies that you used. I just didn't feel like a real teacher to be honest'

'You're always an outsider never fully involved in things because you're just temporary staff. It's day by day, term to term. That's denting my confidence'

Teachers' response to under-employment was to diversify, up-skill and over commit. Some secondary trained teachers worked 'out of field' in longer-term supply posts with little support or additional training. Two teachers (qualified in Art and Design and Religious and Moral Education respectively) had moved into Support for Learning posts, taking opportunities for employment in specialist centres. Job insecurity increased pressure to 'stand out' from peers, positioned as competitors. Individuals took unpaid periods of voluntary work to gain experience, build contacts and 'become known'. Self-initiated and self-funded professional development was seen as important in enhancing employment prospects e.g. taking French language classes (for primary education) and the Catholic Teachers' Certificate by distance learning. Undertaking work and training without remuneration were common forms of self- 
exploitation regarded as necessary in an insecure labour market where initial qualification was no longer sufficient.

'I get involved in everything I can - working groups, after school clubs, extracurricular, course development - so when it comes to job applications and interviews people will see I'm willing to do things. But everybody else is doing the same because folk are just so desperate; they're just trying to do everything to get noticed. If you're not on a permanent contract you've got to do it while you've got the work because you don't know when you'll work again'.

'Even when I was unemployed I was still going into schools and nurseries to do work experience to try to boost my CV'.

The working life of teachers at the periphery is both fragmented (intermittent experience) and segmented (across sectors and settings). Lack of a stable income created pressures to take less qualified support posts or education-related work e.g. unqualified youth work, education officer positions in galleries and museums, nursery officer and classroom assistant posts. Without regular supply work part-time work was found outside teaching in commercial services, commonly in retail, telesales and other call centre work. Teachers could remain available for supply work and stay financially solvent by taking low skilled shift work outside school hours. Under-employment in teaching was often associated with over employment in multiple part-time jobs. In an effort to stabilise her income one teacher was working six days and three nights in two jobs, juggling a temporary teaching post with shifts at a call centre. Another teacher (registered with three council supply registers) who had only secured five days supply in the school term following induction was working evenings and weekends in a retail store and a call centre to pay her mortgage.

'At one point I had a wee bit of supply work for about a week so I was working all day in school and I was working at night. I was working all weekend as well, but you couldn't give any up really'.

'I was out of work for three or four months at a time and I had to sign on for Job Seeker's Allowance. I was going to recruitment agencies looking for temping work or office work and as soon as they see you're a teacher they're not interested. I found that really hard trying to survive on $£ 50$ a week. I had to sign on a few weeks ago because my contract ended and I'm not going to get anything over summer obviously. That's the third time I've signed on and I'm five years out. It's pretty demoralising'.

ECTs emphasised the casualization of teaching in their experiences of 'signing on' for Job Seeker's Allowance and 'signing in' for daily cover, including 'snow days' (school closures through bad weather): 'The council rule is you turn up to your school to sign and you'll get paid for the day.' For some the lack of permanence extended to place of residence. One recently qualified secondary teacher had a system of 'sofa surfing' with friends to remain available for supply work across a large urban authority. Telephoning for work on a daily basis was dispiriting and emphasised a lack of control.

'I had five days work between November and December. You call every single day and get up, get dressed and be ready to go, to be told there's no work. They won't automatically tell you there is no work. They call you back fifteen or thirty minutes later so you are still waiting to see if there's any work that day. It was really soul destroying to only have five days work out of all those days.'

'Having to call every day for work reminds me of the stories my father would tell. He came over from Ireland and to get work you had to go Glasgow Cross every morning and see if there was work on a road gang or a building site. The employers would come along and pick some and the rest had to go back home. That's how supply feels. You feel like you're begging for work. I didn't think I would ever feel so undervalued.' 
Insecurity surrounding employment prospects was felt most acutely by career changers with family responsibilities. Recently qualified primary teachers who had retrained felt let down by reassurances that prospects would improve over time. They did not appreciate the message from government to 'wait their time' when they had been assured that vacancies, even shortages, would arise. Investment in self-development had not paid dividends as they joined the ranks of teacher 'surplus.' A system of local authority 'pool interviews' reinforced feelings that individual expertise and prior experience was not valued.

\begin{abstract}
'How can you live your life if there's no job security? You can't get credit because you've not got a permanent contract. You can't plan your spending because you don't know when you've got money coming in. You can't do any long-term planning. You're frantically trying to save as much as you can in case you don't have work next month. It would be nice to be able to afford things like going on holiday, getting married, all the normal stuff. It's just the practicalities of life like food bills, running a car, getting to work and back; the stress of not being able to do something you want to do and something you've trained for. Not being given the chance to do the job you want to do.'

'If you're good at what you do surely you will get a job at some point somewhere? But it's literally done on how many days you've been working for them. Currently I'm number twelve on the list so as the numbers go up, when I hit number one, whatever job is available next that will be my job.'
\end{abstract}

Although employees on temporary contracts should not be treated less favourably than permanent employees exclusionary practices were not uncommon. These included: not receiving an entitlement to professional learning opportunities or to annual Professional Development and Review meetings with line managers; not having equitable access to classroom resources; and not receiving written details of terms of employment. Temporary teachers' described their position as 'the bottom of the food chain', 'the bottom of the pecking order', and felt poorly placed to lobby for resource and recognition either individually or collectively.

'It's not worth them investing in you because you're not going to be there. They're not going to see the benefits in their school.'

'They are really reluctant to pay for you to come to an in-service. They just see it as another day that they've got to pay you that they don't really need to.'

'You were left with no real resources to equip your classroom because you were last in. Everyone else had sorted their classrooms. The fact that you were supply and not a proper member of staff they were reluctant to give you anything.'

'The supply contract states that if you are in a particular engagement for more than four weeks you will be given a temporary contract, I never have. You don't want to rock the boat and you're just happy that you're getting paid.'

'I'm treated like causal labour because there's only ever a verbal agreement. I've never had a letter of appointment or a contract. There's never been anything in writing. There is no paperwork based around your employment.'

\title{
Career advancement
}

For teachers appointed to 'permanent' posts in the year following induction the 'practice shock' appears delayed and reduced by structured induction. Newly appointed teachers faced common challenges of writing courses, forward planning and moderation with maximum class contact time. Whilst ever short of time and joining school cultures that varied in their level of collegial support, these teachers reported being generally well-equipped to assume the responsibilities of their first posts. Building a repertoire of strategies for behaviour management and deepening 
understanding of assessment practices were identified as priorities in the early years of teaching. The need to be proactive and attend to one's own development needs appears embedded. Professional conversations with line managers (reviewers) positioned the new teacher (reviewee) as holding responsibility for identifying appropriate professional learning opportunities (within budgetary limits). Although support was not tailored to the perceived needs of 'early career teachers' per se, one ECT commented that informal mentoring conversations and habits of help seeking had become routinised.

'You're always asking for advice or you're going and seeing people, sticking your head in to ask questions if you're not sure, and especially starting in a new school. I was still talking to people, it's just I did it off my own back rather than being given a set time each week to do it.'

Positive expressions of professional growth were associated with pedagogical freedom; having the confidence and license to experiment and 'take risks'. Post induction ECTs expressed relief that 'the chains are off', 'no one is looking over my shoulder'. New teachers reported feeling less restricted and more able to use their professional judgement because they felt trusted in a stable set of relationships in 'their' school. A sense of empowerment was accompanied by acceptance of accountability: 'the buck stops with you'.

Attitudes towards career development from year three varied. There are fewer promotion opportunities following the introduction of faculty structures by many Scottish local authorities (McCormac 2011, 27). Opportunities beyond the classroom included participation in online teacher communities (using the national school intranet, GLOW) and elective membership of working parties and committees (e.g. teacher representative on the parent council, school nonattenders' group and cross-curricular initiatives). ECTs expressed growing confidence in their involvement in course development (e.g. adding new courses to the school calendar) and organisation of excursions and events. Opportunities for progression for those with three years' experience included involvement in mentoring, examining, and coordinator roles e.g. literacy coordinator. For some ECTs development opportunities took them away from the classroom e.g. through involvement in teaching adults in further education on a part-time basis or setting up a small business in an area of expertise. A bifurcation of career pathways was apparent between those who sought fulfilment through diversification in their work (horizontal career trajectory, $n=5$ ) and those seeking promotion (vertical career development, $n=2$ ). These two teachers had already obtained acting principal teacher (PT) posts (PT of Guidance (pastoral) and PT subject respectively) through internal appointment. Within this small sample intended career pathways and motivations diverged between 'careerists' who described themselves as 'gunning for promotion' and those who sought professional growth within and outside the mainscale classteacher role.

\section{Limitations}

This study draws on a single round of interviews with a small self-selecting sample and relies on self-report. Preparation pathway and the social and academic background of new teachers were not considered. The notion of teacher quality (however defined) is not approached beyond achievement of full registration. Accounts offered in interview are produced in interaction at a particular moment in time and can only give a partial and indirect insight into participants' working lives (McLeod 2003). The study highlights the volatile nature of the labour market and the current employment status of participants is not known. Whilst this exploratory study addresses temporality (teachers within the first five years of their teaching career), it is a retrospective study. A combination of qualitative and quantitative prospective longitudinal 
research is needed to address the limitations of small-scale studies and official teacher census datasets.

\section{Discussion}

There is nothing unusual about fragmented employment experiences at an early career stage. However the TIS in the first decade of the $21^{\text {st }}$ century created a sense of expectation and security in what turned out to be acutely unstable and insecure times in the wake of the global economic crisis. Teaching in the compulsory schooling sector in the UK has traditionally offered better prospects for full-time employment and long-term security, particularly in comparison with teaching in tertiary education. The re-emergence of idiosyncratic work histories among many ECTs may give new force to Lawrence's $(1993,338)$ claim that, "careers in teaching are being replaced by 'careering' teachers." New teachers are caught between drives to promote career-long professional learning and the reality of restricted opportunities to gain stable employment and career advancement. At the end of induction the emphasis on collegiality and service in the Code of Conduct and Teachers' Standards is countered by experiences of dislocation, exclusion and highly individualised trajectories.

Theories of individualisation are helpful in making sense of the new work context of the 'careering' teacher (Lawrence 1993). Risk consciousness is integral to 'making a career' for oneself in the 'new work order' (Gee et al. 1996). 'Getting in' and 'getting on' require selfconscious entrepreneurial action. At the start of the twenty-first century, management gurus Riddlestrale and Nordstrom $(2000,211)$ offered a reconfiguration of working life as, 'a series of gigs or projects rather than a career'. Whilst not consistent with the 'project world', public sector employment is changing with pay and recruitment freezes, proposed changes to pensions, council budget cuts, increased job insecurity and threats of 'dilution' (unqualified staff). The report on teacher employment in Scotland makes seventeen references to the need for flexibility (McCormac 2011). Flexibilisation invokes new ways for employees to think about themselves. The ideal employee is infinitely adaptable, ready to upskill and focused on the future. Unlike the alienated 'precariat' (Standing 2011:7), the model prospective teacher is malleable and compliant; reluctant to let go of a pact through which investment in selfdevelopment secures entry to the public sector 'salariat' (ibid).

There are dystopian elements in this vision of preparation for work in the risk society (Beck 1992, Beck and Beck-Gernsheim 2002). Within more flexible employment conditions, employees constantly have to renegotiate workplace relationships and identities. For Bauman (2001) the modern workplace has become a 'camping site' from which to 'up sticks' and move when necessary or when a more attractive offer is made, rather than a 'shared domicile' where one works at sustained interaction and attempts to foster a sense of community and belonging. Beck $(2000,3)$ suggests that, 'More and more individuals are encouraged to perform as a 'Me \& Co.', selling themselves in the marketplace'. Notions of 'career' carry different connotations in the do-it-yourself biography. Discontinuity and division are not resisted in new versions of 'professionalism' that emphasise responsible self-development. The work of Richard Sennett (1999) has done much to illustrate the negative consequences of new employment relations.

'A self oriented to the short-term, focused on potential ability, willing to abandon past experience is - to put a kindly face on the matter - an unusual sort of human being. Most people are not like this; they need a sustaining life narrative, they take pride in being good at something specific, and they value the experiences they've lived through. The cultural ideal required in new institutions thus damages many of the people who inhabit them' (Sennett 2006, 5) 
It is not surprising that prolonged precarious employment supplemented by income from career-less shift work produces instrumental orientations to work: 'When I'm not in a school long-term it's just about getting the next day's work and paying the mortgage.' Declining motivation and unrealised expectations may impact on the quality of pupil learning experiences. For others the need for self-actualisation can lead to labour intensification through excessive work, including multiple jobholding. Lack of rootedness can lead to truncated career spans as individuals move across fields in pursuit of security, fulfilment or upward mobility. During periods of economic recession emotional resilience, resourcefulness and initiative will prove much needed attributes if teaching quality is to be fostered and sustained. Teachers who are less well placed to reconfigure life plans in response to changing economic conditions will be most adversely affected, with implications for diversity and equity in the teacher workforce.

Since undertaking this study shrinking council budgets have posed additional challenges for ECTs, including lower remuneration rates for short-term supply work, increased use of unqualified staff in school, and increased class contact for probationers. The proposed removal of specified sets of duties for teachers and support staff from the 2001 Teachers' Agreement may increase teacher workload (McCormac 2011, 16). Termination of the chartered teacher scheme in April 2012 has closed a route to progression for teachers who do not want to leave the classroom (McCormac 2011, 30-32). Greater impetus to 'careering' is found in the encouragement of devolved budgets to schools that will give headteachers power to create temporary promoted posts (McCormac 2011, 28, 32) and to 'recruit staff and move staff on when they are no longer required to deliver what the school wishes to offer' (Cameron 2011, 4). The 'disestablishment' of teaching (Lawrence 1993) through the devolution of powers to school leaders may heighten processes of individualisation.

\section{Conclusion}

Much attention has focused on strengthening school-university partnerships to enhance learning in the 'practicum'. In the Scottish context there has been much investment in strengthening mentoring practices during formal induction. This small-scale study suggests that this work is undermined by intermittent employment experiences in the early years post qualification. At the periphery a 'do-it-yourself' professional biography is assembled from self-initiated self-funded activities. Episodic work histories are unlikely to sustain professional growth, diluting the skills and eroding the confidence of new teachers. Fleeting and shallow workplace relationships, which delineate between 'insider' and 'outsider' groups, are an unlikely source of rich professional learning irrespective of career stage. In times of recession preparing teachers for new patterns of employment is an additional challenge for teacher education. Strategies to promote inclusive and collaborative teacher development will prove important in reducing the isolation of 'painful beginnings' (Huberman 1993). Innovative local partnerships are needed to move forward within conditions of fiscal restraint. An economics of teacher education is required that extends beyond the measurement of 'teacher effects'. Policy deliberation and development in this area is likely to be significantly strengthened by longitudinal research that includes narrative work histories (Goodson 2007) and affords attention to purpose and craft (Sennet 2006).

\section{References}

Allen, R. Burgess, S. \& Mayo, J. 2012. The teacher labour market, teacher turnover and disadvantaged schools: new evidence for England. Bristol: Centre for Market and Public Organisation. 
Anthony, G. \& Ord, K. 2008. Change-of-career secondary teachers: motivations, expectations and intentions. Asia Pacific Journal of Teacher Education 36, no.4: 359-376.

Auguste, B., Kihn, P. \& Miller, M. 2010. Closing the Talent Gap: Attracting and Retaining Top Third Graduates to Careers in Teaching. London: McKinsey \& Company.

Bauman, Z. 2001. The Individualized Society. Cambridge: Polity Press.

Beck, U. 1992. Risk Society. London, Sage.

Beck, U. 2000. The Brave New World of Work. Malden, MA: Polity Press

Beck, U. \& Beck-Gernsheim, E. 2002. Individualization. London: Sage.

Burn, K., Mutton, T. \& Hagger, H. 2010. Strengthening and sustaining professional learning in the second year of teaching. Oxford Review of Education 36, no.6: 639-659.

Caldwell, B. \& Sutton, D. 2010a. Review of Teacher Education and induction. First Report. http://education.qld.gov.au/students/higher-education/resources/review-teachereducation-school-induction-first-full-report.pdf

Caldwell, B. \& Sutton, D. 2010b. Review of Teacher Education and induction. Second Report. http://education.qld.gov.au/students/higher-education/resources/reviewteacher-education-school-induction-full-report.pdf

Cameron, D. 2011. Devolved School Management Review. http://www.scotland.gov.uk/Resource/Doc/920/0121591.pdf

Cameron, M. 2009. Lessons from Beginning Teachers: Challenges for School Leaders. Wellington: Council for Educational Research.

Cameron, M., Baker, R., \& Lovett, S. 2006. Teachers of Promise: Getting Started in Teaching. Wellington: Council for Educational Research.

Cameron, M., Lovett, S. \& Garvey Berger, J. 2007. Starting out in teaching: surviving or thriving as a new teacher. Wellington: Council for Educational Research.

Centre for Public Policy for Regions 2012. Scottish Budget Issues. Briefing Note. http://www.cppr.ac.uk/media/media 237802 en.pdf

Clayton, C.D.G., \& Shoemaker, F. 2007. What holds the academically able teachers in the profession? A study of three teachers. Teachers and Teaching: Theory and Practice 13, no.3: 247-267.

Dall'Alba, G. \& Sandberg, J. 2006. Unveiling Professional Development: A Critical Review of Stage Models. Review of Educational Research 76, no.3: 383-412.

Day, C. 2008. Committed for life? Variations in teachers' work, lives and effectiveness. Journal of Educational Change 9: 243-260.

Day, C., Stobart, G., Sammons, P., Kington, A., Gu, Q., Smees, R. and Mujtaba, T. 2006. Variations in teachers' work, lives and effectiveness. London: Department for Education and Skills.

Day, C., Sammons, P., Stobart, G., Kington, A. \& Gu, Q. 2007. Teachers Matter: Connecting Work, Lives and Effectiveness. Buckingham: Open University Press.

Department for Education 2010. The Importance of Teaching. The Schools White Paper 2010. London: The Stationery Office.

Donaldson, G. 2011. Teaching Scotland's Future. Edinburgh: The Scottish Government.

Education Review Office 2005. Voices: Beginning teachers' experiences during their first two years of teaching. Wellington: Education Review Office.

European Commission 2007. Improving the Quality of Teacher Education. Brussels, European Commission. http://ec.europa.eu/education/com392 en.pdf

Feiman-Nemser, S., \& Remillard, J. 1996. Perspectives on learning to teach. In The Teacher Educator's Handbook ed. F. B. Murray, 63-91. San Francisco: Jossey-Bass. http://ncrtl.msu.edu/http/ipapers/html/pdf/ip953.pdf

Feiman-Nemser, S. 2001. From preparation to practice: designing a continuum to strengthen and sustain teaching. Teachers College Record 103, no.6: 1013-1055. 
Fenwick, A. \& Weir, D. 2010. The impact of disrupted and disjointed early professional development on beginning teachers. Teacher Development 14, no.4: 501-517.

Fenwick, A. 2011. The first three years: experiences of early career teachers, Teachers and Teaching 17, no.3: 325-343.

Gee, J. P., Hull, G. \& Lankshear, C. 1996. The New Work Order: Behind the language of the new capitalism. Sydney: Allen Unwin.

General Teaching Council of Scotland 2006a. Standard for Initial Teacher Education. Edinburgh, GTCS.

General Teaching Council of Scotland 2006b. Standard for Full Registration. Edinburgh, GTCS.

General Teaching Council Scotland, 2010a. Teacher induction scheme employment survey. October 2010. http://www.gtcs.org.uk/web/FILES/FormUploads/employment-surveyreport-probationer-teacher-2009-10-233470 767.pdf

General Teaching Council Scotland. 2010b. Employment Follow-up Survey 2008/09. Probationer teachers May 2010. http://www.gtcs.org.uk/web/FILES/FormUploads/employment-survey-2008-2009follow-up-update.pdf

General Teaching Council Scotland. 2011. Employment Follow-up Survey 2009/10. Probationer teachers June 2011. http:/www.gtcs.org.uk/web/FILES/FormUploads/2009-2010-employment-follow-upsurvey-report-june-201137851 873.pdf

General Teaching Council Scotland. 2012. General Teaching Council expectations in respect of the Teacher Induction Scheme. April 2012.

http://www.probationerteacherscotland.org.uk/teacher-induction-scheme/classcontact-time.aspx

Goodson, I. F. 2005. Learning, Curriculum and Life Politics. London: Routledge.

Goodson, I. F. 2004. Professional Knowledge, Professional Lives. Studies in Education and Change. Maidenhead: Open University Press.

Goodson, I.F. 2007. All the lonely people: the struggle for private meaning and public purpose in education. Critical Studies in Education 48, no.1: 131-148.

Griffiths, V. 2011. Career changers and fast-track induction: teacher perspectives on their early professional development. Teacher Development 15, no.1: 19-35.

Henry, G.T., Bastian, K.C. \& Fortner, C.K. 2011. Stayers and Leavers: Early-Career Teacher Effectiveness and Attrition. Educational Researcher 40, no.6: 271-280.

Hobson, A.J., Malderez, A., Tracey, L., Homer, M.S., Ashby, P., Mitchell, N., McIntyre, J., Cooper, D., Roper, T., Chambers, G.N. \& Tomlinson, P.D. 2009. Becoming a Teacher: Teachers' experiences of initial teacher training, Induction and early professional development (Final report). Nottingham: Department for Children, Schools and Families.

Huberman, M. 1989. The professional life cycle of teachers. Teachers College Record 91, no. 1: 31-57.

Huberman, M. 1993. The Lives of Teachers. New York: Teachers College Press.

Hutchings, M. 2011. What impact does the wider economic situation have on teachers' career decisions? A Literature Review. DfE-RR136. https://www.education.gov.uk/publications/eOrderingDownload/DFE-RR136.pdf

Ingersoll, R. 2001. Teacher Turnover, Teacher Shortages and the Organization of Schools. Center for the Study of Teaching and Policy, University of Washington.

Jenkins, K., Smith, H. \& Maxwell, T. 2009. Challenging experiences faced by beginning casual teachers: here today and gone the next! Asia Pacific Journal of Teacher Education 37, no.1: 63-78. 
Johnson, S. M. 2004. Finders and Keepers. Helping New Teachers Survive and Thrive in Our Schools. The Project on the Next Generation of Teachers. San Francisco, CA: Jossey Bass.

Johnson, S. M. 2006. The Workplace Matters: Teacher Quality, Retention, and Effectiveness. Washington, DC: National Education Association.

Kaiser, A. 2011. Beginning Teacher Attrition and Mobility: Results From the First Through Third Waves of the 2007-08 Beginning Teacher Longitudinal Study (NCES 2011318). U.S. Department of Education. Washington, DC: National Center for Education Statistics.

Kidner, C. 2011. Scottish Parliament Information Centre Briefing. Teacher Numbers. http://www.scottish.parliament.uk/ResearchBriefingsAndFactsheets/S3/SB 11-08.pdf

Lawrence, D. 1993. The disestablishment of teachers' careers. Oxford Review of Education 19: 337-53.

Lovett, S. \& Cameron, M. 2011a. Schools as professional learning communities for earlycareer teachers: how do early-career teachers rate them? Teacher Development 15, no. 1: 87-104.

Lovett, S. \& Cameron, M. 2011b. Career pathways: does remaining close to the classroom matter for early career teachers? A study of practice in New Zealand and the USA, Professional Development in Education 37, no.2: 213-224.

Mason, R.W. \& Schroeder, M.P. 2010. Principal Hiring Practices: Toward a Reduction of Uncertainty. The Clearing House 83: 186-193.

McCormac, G. 2011. Advancing Professionalism in Teaching. http://www.scotland.gov.uk/Resource/Doc/357766/0120894.pdf

McCormack, A., Gore, J. \& Thomas, K. 2006. Early Career Teacher Professional Learning. Asia-Pacific Journal of Teacher Education 34, no.1: 95-113.

McLeod, J. 2003. Why we interview now: Reflexivity and perspective in a longitudinal study. International Journal of Social Research Methodology 6, no.3: 201-211.

McNally, J., Boreham, N., Cope, P., \& Stronach, I. 2008. Enhanced Competence-Based Learning in Early Professional Development: Full research report. Swindon: ESRC.

Moir, E., Barlin, D., Gless, J. \& Miles, J. 2009. New Teacher Mentoring. Hopes and Promise for Improving Teacher Effectiveness. Cambridge, MA: Harvard Educational Press.

Moor, H., Halsey, K., Jones, M., Marin, K., Stott, A., Brown, C., \& Harland, J. 2005. Professional development for teachers early in their careers: An evaluation of the early professional development pilot scheme. London: DfES.

National Research Council 2010. Preparing teachers: building evidence for sound policy. Committee on the Study of Teacher Preparation Programs in the United States, Center for Education. Division of Behavioral and Social Sciences and Education. Washington, DC: The National Academies Press.

Organisation for Economic Cooperation and Development. 2005. Teachers Matter: Attracting, Developing and Retaining Effective Teachers. Paris: OECD.

Organisation for Economic Cooperation and Development. 2007a. Improving the Quality of Teacher Education. Paris: OECD.

Organisation for Economic Cooperation and Development. 2007b. Quality and Equity of Schooling in Scotland. Paris: OECD.

Organisation for Economic Cooperation and Development. 2011. Building a High-Quality Teaching Profession: Lessons from around the World. Paris: OECD.

Parker, M.A., Ndoye, A. \& Imig, S.R. 2009. Keeping our teachers! Investigating mentoring practices to support and retain novice educators. Mentoring and Tutoring 17, no.4: 329-341. 
Pietsch, M. \& Williamson, J. 2010. 'Getting the pieces together': negotiating the transition from pre-service to in-service teacher. Asia-Pacific Journal of Teacher Education 38, no.4: 331-344.

Ridderstrale, J. \& Nordstrom, K. 2000. Funky Capitalism. London: Pearson.

Schuck, S., Aubusson, P., Buchanan, J., Prescott, A., Louviere, J. \& Burke, P. 2011. Retaining Effective Early Career Teachers in NSW Schools. http://www.rilc.uts.edu.au/pdfs/Beginning Teacher_Retention_Report.pdf

Scott, C. \& Dinham, S. (2008) Born not made: the nativist myth and teachers' thinking. Teacher Development 12, no.2: 115-124.

Scottish Executive. 2001. A Teaching Profession for the $21^{\text {st }}$ century. Edinburgh: Scottish Executive.

Scottish Government. 2010a. Scotland's Spending Plans and Draft Budget 2011-12. http://www.scotland.gov.uk/Publications/2010/11/17091127/0

Scottish Government. 2010b. Summary Statistics for Schools in Scotland, No.1: 2010 Edition. http://www.scotland.gov.uk/Resource/Doc/91982/0119944.pdf

Scottish Government. 2011a. Summary Statistics for Schools in Scotland, No.2: 2011 edition

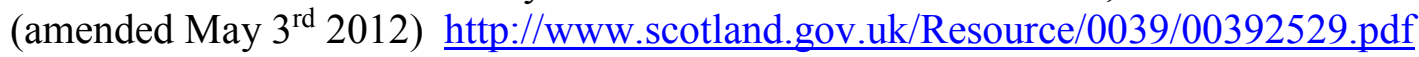

Scottish Government. 2011b. Employment for teachers in Scotland. News Release. 20/01/2011. http://www.scotland.gov.uk/News/Releases/2011/01/20145753

Sennett, R. 1999. The Corrosion of Character. The personal Consequences of Work in the New Capitalism. New York: W.W. Norton.

Sennett, R. 2006. The Culture of the New Capitalism. The Castle Lectures in Ethics, Politics and Economics. New Haven/London: Yale University Press.

Smethem, L. 2007. Retention and intention in teaching careers: will the new generation stay? Teachers \& Teaching 13, no.5: 465-480.

Smithers, A. and Robinson, P. 2003. Factors Affecting Teachers' Decisions to Leave the Profession. Department for Education and Skills, RR430. London: DfES.

Standing, G. 2011. The Precariat. The New Dangerous Classes. London: Bloomsbury.

Sturges, J.E. \& Hanrahan, K.J. 2004. Comparing telephone and face-to-face qualitative interviewing: A research note. Qualitative Research 4, no.1:107-118.

Teaching Council. 2011. Policy on the Continuum of Teacher Education. Maynooth: The Teaching Council.

Turnbull, B. 2004. High expectations: untenured teacher involvement in school decisionmaking. Teaching Education 15, no.3: 311-318.

Williams, A. \& Prestage, S. 2001. Individualism to collaboration the significance of teacher culture to the induction of newly qualified teachers. Journal of Education for Teaching 27, no.3: 252-267. 